\title{
Lars Hartman
}

\section{Approaching New Testament Texts and Contexts}

\author{
Collected Essays II \\ Ed. by Tord Fornberg and David Hellholm
}

[Annäherung an Texte und Kontexte des Neuen Testaments.]

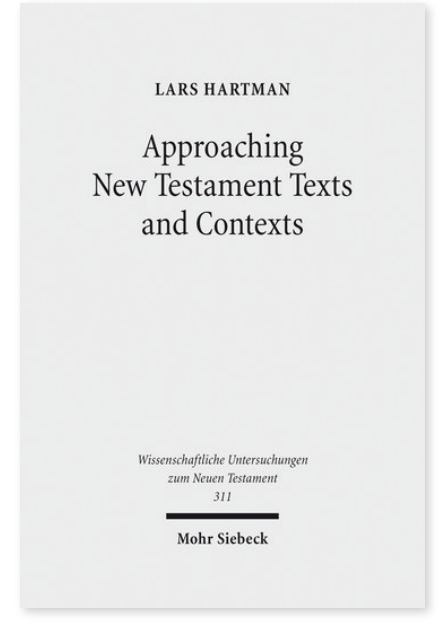

2013. XI, 382 Seiten. WUNT I 311

ISBN 978-3-16-152354-0

DOI 10.1628/978-3-16-152354-0

eBook PDF $159,00 €$

ISBN 978-3-16-152319-9

Leinen $159,00 €$
Veröffentlicht auf Englisch.

In diesem Band behandelt Lars Hartman viele wichtige Themengebiete. Einige seiner Aufsätze sind exegetischen und hermeneutischen Problemen gewidmet, so zum Beispiel den theoretischen Betrachtungen im Bezug darauf, was es bedeutet, einen Kommentar zu schreiben. Die folgenden Aufsätze sind detaillierte Untersuchungen diverser Aspekte der Textanalyse als Vorbereitung seines Kommentars zum Markusevangelium. Des weiteren hat Hartman wegweisende Texte zur Taufe geschrieben, im Besonderen hinsichtlich der Namensformel. Die letzten Aufsätze befassen sich mit dem hellenistischen Kontext zahlreicher Texte und Themen des Neuen Testaments, wie zum Beispiel die Untersuchung »Hellenistische Elemente in apokalyptischen Texten«. Dieser Band ist eine angemessene Ergänzung zu Lars Hartmans früherer Sammlung textbezogener Untersuchungen zum Neuen Testament aus dem Jahre 1997.

Lars Hartman Born 1930; 1957 ordained priest in the Lutheran Church of Sweden; 1966 ThD and Habilitation; 1971-90 Professor for New Testament Exegesis at Uppsala University; 1990-95 Director of the Church of Sweden Research Department; 1995 retirement; 2011 doctor honoris causa at Helsinki University.

Tord Fornberg Born 1943; 1977 ThD; 1988 Habilitation, both at Uppsala University; taught at the same university until his retirement in 2008; presently teaching at the Newman Institute in Uppsala; member of the Commission for Inter-Religious Dialogue of the Catholic Diocese of Stockholm.

David Hellholm Born 1941; 1980 Dr. theol.; 1982 Habilitation; 1979-83 assistant professor at the University of Linköping (Sweden); 1983-89 associate professor at the University of Bergen (Norway); 1990-2008 full professor of New Testament and its environment at the University of Oslo (Norway); since 2008 Emeritus.

Jetzt bestellen:

https://mohrsiebeck.com/buch/approaching-new-testament-texts-and-contexts-9783161523540?no_cache=1 order@mohrsiebeck.com

Telefon: +49 (0)7071-923-17

Telefax: +49(0)7071-51104 